\title{
Board Governance Diversity and The International Decision of Indonesia's Service Companies
}

\author{
ZAITUL ${ }^{1}$, ZERNI MELMUSI ${ }^{2}$, DESI ILONA ${ }^{3 *}$ \\ ${ }^{1}$ Faculty of Economics and Business, UNIVERSITAS BUNG HATTA, INDONESIA \\ ${ }^{2}$ Faculty of Economics and Business, UNIVERSITAS PUTRA INDONESIA YPTK, INDONESIA \\ ${ }^{3}$ Faculty of Economics and Business, UNIVERSITAS PUTRA INDONESIA YPTK, INDONESIA \\ E-mail: desiilona@upiyptk.ac.id
}

\begin{abstract}
Even though the Board of Commissioners has a significant role in making an optimal international decision, there is a limited empirical finding using data from the Unique Continental corporate governance system, such as Indonesia. This study examines the relationship between the Board of Commissioners diversity and service companies' international decision. Specifically, this study investigates the effect of ethnic, nationality, qualification, and experience diversity of Board of Commissioners on the international decision. A company with a high Board of Commissioners diversity tends to have more effective monitoring the Management Board and therefore reduce the agency cost and the company performance. Ninety-nine service companies listed in Indonesia's stock exchange has participated in this study. As this study using the multivariate regression analysis, the classical assumptions must be satisfied. The result shows that ethnic, qualification and experience diversity have a significant effect on the international decision. Besides, company size tends to have a better position to sell in the foreign market. A company with higher leverage is likely to have a higher international decision. Theoretically, this research implies that board governance diversity in a unique two-tier board model could also be explained by agency theory. This finding also shows that the company can increase the international decision by increasing the Board of Commissioners' qualification and experience diversity. However, the Board of Commissioners ethnic diversity should be reduced to increase the international decision.
\end{abstract}

Keywords: Board of Commissioners Diversity, International Decision

JEL Classification: M16, M41

Recibido: 7 de Diciembre de 2020

Aceptado: 3 de Marzo de 2021 


\section{Introduction}

International strategy is one of the strategies that a company should take to gain competitive advantages. International strategy is a crucial strategy for companies in developing markets (Lian and Chen, 2017). Several terminologies for international company activity are used in the literature, such as internationalization, international decision, international performance, etc. For example, Calabrò, Campopiano, Basco, and Pukall (2017) conceptualize international activity as internationalization. Several variables affect the company internationalization or international decision based on several research types (Evers and Knight, 2008; Li, 2018; Monks and Minow, 2004). Company international decision is an outcome of corporate governance system and structure (Monks and Minow, 2004), Top management team characteristics (Li, 2018), networking (Evers and Knight, 2008; Kampouri, Plakoyiannaki, and Leppäaho, 2017).

In a two-tier board system, the Board of Commissioners responsible to actively control and monitor the Management Board's behaviour to make certain that their decisions are based on shareholders' interest (Jungmann, 2006), and develop the company's strategy, such as international's strategy (Calabrò et al., 2017). Ideally, using a two-tier board system will effectively achieve company outcomes for shareholders and other stakeholders (Shan and Mclver, 2011). Furthermore, Indonesia is one of the countries that adopt a two-tier board system (Ilona et al., 2019; Zaitul et al., 2018; Zaitul, Elfiswandib, et al., 2019; Zaitul, Melmusi, et al., 2019; Zaitul and Ilona, 2018). Darmadi (2016) states that Indonesia's corporate governance system already exists, but the practice is still left behind. This contention is also supported by Nuryanah and Islam (2011). They note that corporate governance practices are less effective in Indonesia. Cheong and Sinnakkannu (2014) claim that independent board monitoring does not conduct effectively. Top Management Team diversity creates a wider pool of experience, skills, value, and knowledge that could positively benefit business outcomes such as internationalization (Alayo, Maseda, Iturralde, and Arzubiaga, 2019). The relationship between the Board of Commissioners and decision has been explained by agency theory. The Board of commissioners ratify the management board or Board of director's initiatives and control the execution made by the Board of the director. Therefore, international decision making involves the Board of the director. However, there are limited empirical findings using data from a unique continental European corporate governance system. Most previous studies have been done in a country that follows an Anglo-Saxon corporate governance system.

Previous studies that have paid attention to the international decision are focused on board composition, size, and CEO duality (Nas and Kalaycioglu, 2016), political experience of Board (Yarbrough, Abebe, and Dadanlar, 2017), strategic sustainability management (Vencato, Gomes, Scherer, Kneipp, and Bichueti, 2014), and financial development and ownership (Lian and Chen, 2017), top management team characteristics (Li, 2018; Ramón-Llorens, García-Meca, and Duréndez, 2017), governance structure as measured with Management Board, Board of Commissioners, and ownership (Calabrò et al., 2017; Nam, Liu, Lioliou, and Jeong, 2018). However, the number of papers on Board of Commissioners diversity has been relatively none. Further, Segaro (2012) suggests that board composition affects international decision. Thus, the present study uses the Board of Commissioners' diversity to enhance Indonesia's listed companies' better international decisions. Because diversity may increase group performance because they bring diverse skills, ability, knowledge, and priorities to solve problem-solving (Harjoto, Laksmana, and Yang, 2018, Khan et al. 2020). This research makes several contributions. First, this study investigates the role of the Board of Commissioners (ethnic, nationality, qualification, and experience diversity) on the international decision. Second, it contributes to corporate governance literature, especially in the Continental European context. A study on the Board of Commissioners and the international decision has been done (Calabrò et al., 2017; Nam, Liu, Lioliou, and Jeong, 2018). However, Nam et al. (2018) employ the company data from Korea, which is adopted the Anglo-Saxon corporate governance system. Also, Calabrò et al. (2017) use the Germany company data, which implements the Continental European corporate governance system. However, it differed with Indonesia in term of appointing and dismissed the board governance. 
In most countries that adopted the Continental European corporate governance system, the Board of Commissioners is appointed and dismissed by shareholders.

Moreover, the management board is selected by the Board of Commissioners. In Indonesia, however, both boards are elected by shareholders. Finally, this finding can configure the Board of Commissioners members. The rest of the paper is organized as follow. The first session is the background of the study. The theory and hypothesis development is discussed in the following session. The research methodology is showed in the third session. The result and discussion are explained in the fourth session. Finally, this paper is closed by conclusion and recommendation.

\section{Theoretical Aspect and Hypotheses}

La Porta et al. (2000) argue that corporate governance is a set of procedures for protecting the outside shareholders' interest from company insiders. According to Chiang and Lin (2007), corporate Governance is a set of rules to align the interest between the Board of Directors, shareholders, and other stakeholders in a company. According to agency theory (Jensen and Meckling, 1976), performance is the consequences of agency problem and cost. If the agency problem or cost minimalize, the performance will increase. An agency problem arises from principal-agent conflict (Fama and Jensen, 1983). Therefore, the principal assign Board of Commissioners oversees Management Board.

Further, the Board of Commissioners plays an important role in minimalizing the agency cost and increasing the international decision. Thus, it needs the Board of Commissioners to align the Management Board and shareholders (Jensen and Meckling, 1976). The diversity of the Board of Commissioners could enhance corporate governance practice better. The Board of diversity is better at producing linkages with critical outside stakeholders (Kagzi and Guha, 2018). The research framework is demonstrated in Figure 1.

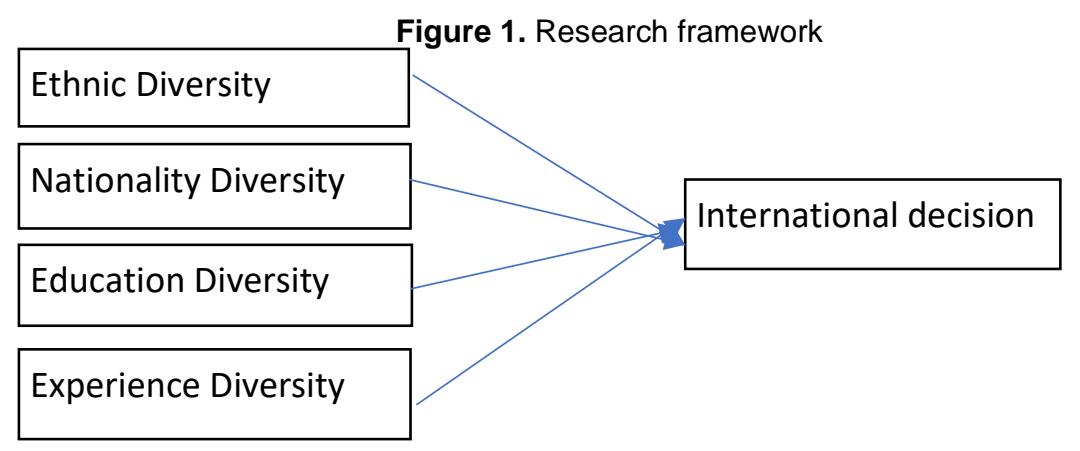

\subsection{Ethnic diversity}

Indonesia consists of more than 17.000 islands, from Sabang to Merauke. It has more than 300 ethnics, such as Java, Melayu, Batak, Chinese, and others. Java is known as the largest ethnic group. It around $41 \%$ of the Indonesian population from java. Further, most of the Indonesian leader is from this ethnic. Each ethnic brings different ideologies, beliefs, cultures, and attitudes that impact their way of thinking, directing, and making decisions (Abdul, Marzuk, Jaafar, and Masron, 2018). Agency theory believes that various ethnics on the Board of Commissioners are expected to monitor and control Management Board, effectively reducing agency costs (Carter, Simkins, and Simpson, 2003). The Board of Commissioners comes from various ethnic backgrounds will indirectly impact the Board of Commissioners members' action. Board with diverse ethnics has a different culture, experience and more informative (Erhardt, Werbel, and Shrader, 2003). Milliken and Martins (1996) suggest that various ethnic board members negatively affect individual and company performance. Abdul et al. (2018) examines the effect of ethnic diversity as measured by the percentage of Bumiputra directors on total director's remuneration. They find a negative relationship between ethnic diversity and total director's remuneration. Study in the US, Carter et al. (2003) finds that diverse ethnic on Board does not value financial performance. In contrast, Cheong and Sinnakkannu (2014) obtain that ethnic 
diversity positively and significantly impacts financial performance. Therefore, the first hypotheses are as below:

H1: Ethnic diversity of Board of Commissioners contributes to better international decision

\subsection{Nationality diversity}

Global competition has a significant impact on the Board of Commissioners composition. According to Bozec (2005), competition could increase company performance within the same industry. The Board of Commissioners should be from various countries worldwide to respond to that competition. Diversity in the nationality of Board of Commissioners will encourage better global relationship (Wang and Clift, 2009), prepare independent and expertise in monitoring the Management Board's action (Ameer, Ramli, \& Zakaria, 2010; Choi, Sul, and Min, 2012), bring the interests of Management Board and owners closer together (Oxelheim and Rand $\varnothing y, 2003$ ), and give good signals and enhance reputation to the global market (Muttakin, Khan, and Subramaniam, 2015). Besides, the Board's international experience will reduce the possibility of failure in the international market through efficiency and effective use of company resources (Li, 2018). However, Ujunwa, Okoyeuzu, and Nwakoby (2012) believe that foreign Board is less understand about domestic issues and, therefore, less effective in their task. Thus, the collaboration between foreign and local Boards will bring different knowledge, priorities, and understanding of problem-solving that could enhance better international decisions.

A most prior study investigating the effect of foreign Board on company performance is positively documented (e.g., Ameer et al., 2010; Choi et al., 2012; Rose, 2007). Using 277 non-listed Malaysian companies from 2002-2007, Ameer et al. (2010) find that foreign boards' present could enhance better company performance. However, Rose (2007) finds that the percentage of foreign Commissioners' percentage does not affect company performance. However, the lack of studies discusses nationality diversity and company performance (Harjoto et al., 2018; Ujunwa et al., 2012). Harjoto et al. (2018) investigate nationality diversity and company performance. They find that the Board's nationality diversity is associated with good corporate social responsibility. At the same time, Li (2018) finds a positive effect between the top management team's international experience and internalization. However, there is no study examining the contribution of Board of Commissioners nationality diversity for better international decisions. The first hypothesis is as follows:

$\mathrm{H} 2$ : The nationality diversity of the Board of Commissioners contributes to a better international decision.

\subsection{Education diversity}

The Board of Commissioners' role is to monitor and advise the strategies taken by the Management Board. This role will be reached if the Board of Commissioners members have variation in educational background. Chiang and He (2010) note that the Board with higher-level educational degrees has better knowledge than a low-level educational background. Cheng, Chan, and Leung (2010) believe that the Board's intellectual competence generally reflects their education background. In contrast, Darmadi (2013) believes that education background is not always one factor that should be considered in board members' appointment. While Kuo, Wang, and Yeh (2018) argue that the Board, with a higher education level, tends to use its resources for innovation. A previous study that examines the impact of educational diversity on performance is limited (e.g., Harjoto et al., 2018; Kagzi and Guha, 2018). It is also supported by prior investigators of Darmadi (2013). They note that researcher less investigate education diversity. The findings of prior studies show mix results. (Kagzi and Guha, 2018) find that education diversity has a negative impact on company performance. Vice versa, Kuo et al. (2018) find a positive relationship between board education diversity and the company's R\&D investment. Darmadi (2013) investigates the impact of the Board of Commissioners' educational qualification for 160 companies listed on the IDX (Indonesia Stock Exchange). He finds that the Board of Commissioners' educational background does not influence their capability to monitor and advise the Management 
Board to increase company performance. Tseng and Jian (2016) find that the Board with a graduate from foreign universities, top universities, and top MBA programs is associated with company branding outcomes. Based on the above discussion, the hypothesis is as follow:

H3: Education diversity of Board of Commissioners contributes to better international decision

\subsection{Experience diversity}

Siciliano (1996) concludes that board members with various occupational backgrounds provide resources to the company. Board of Commissioners experience and professional knowledge increase strategic and monitoring roles (Garcia-Torea, Fernandez-Feijoo, and de la Cuesta, 2016) and justify issues associated with managerial and financial performance (Shan and Mclver, 2011). Also, Yarbrough et al. (2017) add that the Board's political experience provides network access, resources, and guidance to enhance international decision. Kroll, Walters, and Wright (2008) argue that directors will become engaged in monitoring and advising with experience because, through experiential learning, they may contribute positively to company outcomes. The Board of Directors' diverse experience may bring about innovative and creative decision-making. Besides, increasing the number of Board of Commissioners with work experience or professional knowledge places them in a better position to enhance company performance (Shan and Mclver, 2011). Boards need more competency and skills in developing a strategy on their own (Hossan, Sarket, and Afroze, 2012). From 156 large US companies, Yarbrough et al. (2017) find that the Board's political experience has a positive impact on company internationalization strategy. Shan and Mclver (2011) investigate the effect of the Board of Commissioners members' work experience on company performance for 117 companies listed on Chinese stock exchanges. They find that the Board of Commissioners' work experience has no contribution to company performance. Badu and Appiah (2017) also find that board experience has no relationship with agency conflict. Thus, the next set of hypotheses is:

H4: Experience diversity of Board of Commissioners contributes to better international decision

\section{Methodology}

As this study is conducted on Indonesian listed companies, each director of service companies' data was hand-collected from annual reports (2012 to 2016) available on the IDX. This observation is adequate, with three hundred eighty companies-years and nine variables (Krejcie and Morgan,1970; Sekaran, 2006; Hair et al., 2006). Krejcie and Morgan (1970) propose that ninety-five populations, seventy-six companies as sample is adequate. Besides, Sekaran (2006) argue that a sample size around 30 to 500 is appropriate for most research. Further, three hundred eighty observation is much larger than three hundred forty-five. According to Lian and Chen (2017), there are two models involved in the international decision that are exporting and OFDI (Outward Foreign Direct Investment). In this study, the international decision is measured by international revenue to total revenues (Calabrò, Torchia, Pukall, and Mussolino, 2013). The present study employs the Blau index to measure the Board of Commissioners diversity (Blau, 1977) and used by Kagzi and Guha (2018). Ethnic diversity is categorized into Java, Sunda, Chinese, and others. Nationality consists of Indonesian, Malaysian, Chinese, Singapore and others. Further, this study measures education diversity into four board's education disciplines: Economics, Engineering, Law and others. Experience diversity is measured by directors, accountants, business and others. Besides, this study also employs several control variables, such as company age (Arosa, Iturralde, and Maseda, 2010; Calabrò et al., 2013), size (Calabrò et al., 2013; Campbell and Mínguez-Vera, 2008), leverage (Mak and Kusnadi, 2005) and profitability. Multivariate regression analysis is applied to analyse the data. (Gujarati, 1995) propose the classical assumption tests before using the $p$-value and coefficient, such as the normality test. The multivariate regression model is shown below.

$$
\begin{gathered}
\text { InDe }=\alpha+\beta_{1} \text { EtDiv it }+\beta_{2} \text { NaDiv it }+\beta_{3} \text { EdDiv it }+\beta_{4} \text { ExDiv it }+\beta_{5} \text { Age it }+\beta_{6} \text { Size it }+ \\
\beta_{7} \text { Lev it }+\beta_{8} \text { Pro it }+\varepsilon
\end{gathered}
$$


Where:

$\begin{array}{ll}\text { InDe } & =\text { International decision, } \\ \text { EtDiv } & =\text { Ethnic diversity of Board of Commissioners } \\ \text { NaDiv } & =\text { Nationality diversity of Board of Commissioners } \\ \text { EdDiv } & =\text { Education diversity of Board of Commissioners } \\ \text { ExDiv } & =\text { Experience diversity of Board of Commissioners } \\ \text { Age } & =\text { Age of company } \\ \text { Size } & =\text { Size of company } \\ \text { Lev } & =\text { Leverage of company } \\ \text { Pro } & =\text { Profitability of company }\end{array}$

\section{Result and discussion}

Service companies listed in the Indonesia stock exchange is a research object. The final observation is three hundred and eighty companies-years during 2012-2016. The statistic descriptive of research variables is demonstrated in Table 1 . International revenues are $9.82 \%$, with a maximum value of $42.30 \%$. Board of Commissioners ethnic diversity is 0.37 with 0.67 of maximum value.

Meanwhile, the Board of Commissioners national diversity is 0.09 , and its standard deviation is 0.20. Besides, the Board of Commissioners education diversity is 0.32 and 0.24 for standard deviation. Further, the Board of Commissioners experience diversity is 0.31 , and its maximum value is 0.81 . Thus, the mean value of control variables is 39.59 years, Rp. 42.11 trillion, $63.74 \%$ and $3.56 \%$ for company age, company size, company leverage and company profitability.

Table 1. Statistic Descriptive of Research Variables

\begin{tabular}{|c|c|c|c|c|c|}
\hline Variables & $\mathbf{N}$ & Minimum & Maximum & Mean & Std. Deviation \\
\hline InDe (\%) & 380 & 0.00 & 42.30 & 9.82 & 0.41 \\
\hline EtDiv (Index) & 380 & 0.00 & 0.67 & 0.37 & 0.22 \\
\hline NaDiv (index) & 380 & 0.00 & 0.65 & 0.09 & 0.20 \\
\hline EdDiv (Index) & 380 & 0.00 & 1.00 & 0.32 & 0.24 \\
\hline ExDiv (index) & 380 & 0.00 & 0.81 & 0.31 & 0.25 \\
\hline Age (year) & 380 & 5.00 & 110.00 & 39.59 & 19.76 \\
\hline Size (Rp. Million) & 380 & 38,646 & $1,003,644,426$ & $42,108,329$ & $130,273,995$ \\
\hline Lev (\%) & 380 & 0.09 & 99.46 & 63.74 & 28.59 \\
\hline Pro (\%) & 380 & -7.67 & 26.23 & 3.56 & 4.95 \\
\hline
\end{tabular}

Notes: InDe (international decision), EtDiv (ethnic diversity of Board of Commissioners), NaDiv (nationality diversity of Board of Commissioners), EdDiv (education diversity of Board of Commissioners), ExDiv (experience diversity of Board of Commissioners), Age (Age of company), Size (size of the company), Lev (leverage of company), and Pro (profitability of company).

This study uses multivariate regression analysis. Before regression analysis, the classical assumptions may be satisfied first. The normality test is the first classical assumption. In this case, the normality P-P plot is used. The result shows that the data is normal. The second assumption is the multicollinearity problem. In this study, the variance inflation factor (VIF) is used to see any correlations among independent variables. The result finds no correlation between independent variables since the value of VIF is lesser than 10 (see table 2). 
Figure 1. Normal P-P plot

\section{Normal P-P Plot of Regression Standardized Residual}

Dependent Variable: InPer

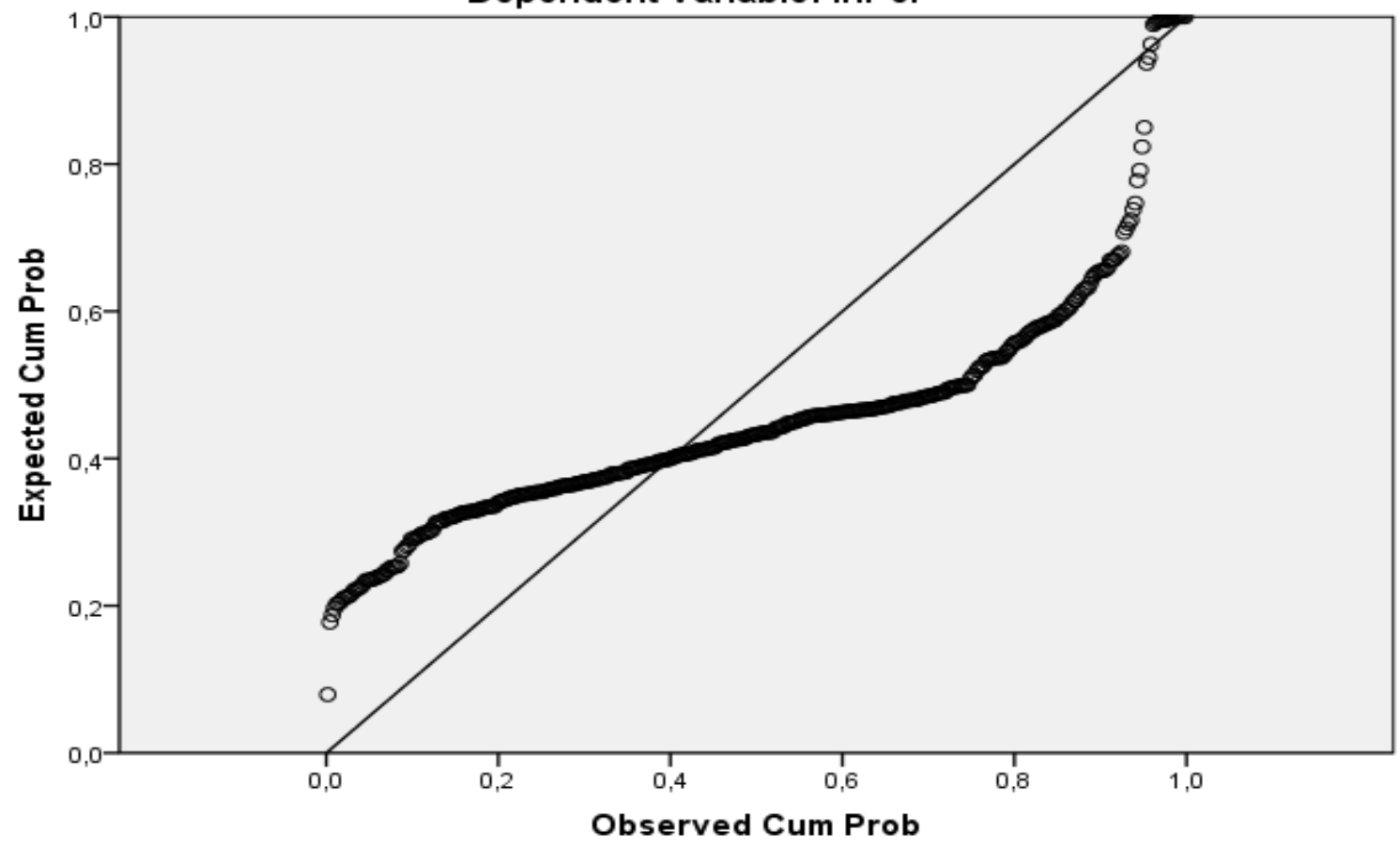

Model 1 shows the multivariate regression analysis using control variables as independent variables against the dependent variable (international decision). F statistic for model 1 is 4.49 , with a $p$-value of 0.00 , and it can be concluded that the model is fit. R-square is $4.60 \%$, and it means that independent variables explain $4.60 \%$ of dependent variables. Based on the $t$ statistic, two control variables significantly affect the international decision. First, company size has a positive impact on the international decision. It means that big company tends to have a higher international decision. Second, the company leverage also has a positive effect on the international decision. It can be concluded that the company with higher leverage is likely to have a higher international decision.

Table 2. The Result of Regression Analysis

\begin{tabular}{|c|c|c|c|c|c|}
\hline \multirow{2}{*}{ Variables } & \multicolumn{2}{|c|}{ Model 1} & \multicolumn{2}{|c|}{ Model 2} & \multirow[t]{2}{*}{ VIF } \\
\hline & Coef Reg & t stat & Coef Reg & t stat & \\
\hline EtDiv & - & - & -0.39 & $-3.99^{* * *}$ & 1.51 \\
\hline NaDiv & - & - & 0.09 & 0.78 & 1.17 \\
\hline EdDiv & - & - & 0.15 & $1.66^{*}$ & 1.25 \\
\hline ExDiv & - & - & 0.18 & $2.12^{\star *}$ & 1.11 \\
\hline Age & 0.00 & -0.20 & -0.00 & -0.67 & 1.27 \\
\hline Size & 0.00 & $2.54^{* *}$ & 0.00 & $2.14^{\star *}$ & 1.18 \\
\hline Lev & 0.00 & $1.91^{*}$ & 0.00 & $2.61^{* * *}$ & 1.23 \\
\hline Pro & -0.00 & -1.46 & -0.00 & -0.39 & 1.15 \\
\hline F stat & \multicolumn{2}{|c|}{4.49} & \multicolumn{2}{|c|}{4.98} & \\
\hline $\mathrm{F}$ sig & \multicolumn{2}{|c|}{$0.00^{* * *}$} & \multicolumn{2}{|c|}{$0.00^{* * *}$} & \\
\hline R square (\%) & \multicolumn{2}{|c|}{4.60} & \multicolumn{2}{|c|}{9.70} & \\
\hline
\end{tabular}

Notes: ${ }^{*},{ }^{* *}$, and ${ }^{* * *}$ indicate significant at $10 \%, 5 \%$, and $1 \%$. EtDiv (ethnic diversity of Board of Commissioners), NaDiv (nationality diversity of Board of Commissioners), EdDiv (education diversity of Board of Commissioners), ExDiv (experience diversity of Board of Commissioners), Age (Age of company), Size (size of the company), Lev (leverage of company), and Pro (profitability of company). 
The second model adds the hypotheses variables in the model. F statistic and F significant are 4.98 and 0.00 , respectively. Therefore, the model is very much fit because its $F$ significant value is lower than $0.01(\alpha<0.01)$. In addition, the $R$ square is 9.70 , which is higher than the $R$ square of the first model. It means that there is an effect of additional variables in the model ( $R$ square change is 5.10)Board of Commissioners ethnic diversity $(\alpha<0.01)$ has a negative effect on the international decision. A company with higher Board of Commissioners ethnic diversity contribute to lower international decision. Besides, the Board of Commissioners education diversity has a positive effect on company international decision. A company with a higher Board of Commissioners education diversity tends to have a higher international decision.

Further, the Board of Commissioners diversity has a positive association with the international decision. It means that the higher the Board of Commissioners experience, the higher the international decision. However, the effect of the Board of Commissioners nationality diversity on the international decision is not significant.

The negative effect of the Board of Commissioners ethnic diversity on the international decision may be difficult to explain, but it may be related to Kochan et al. (2003), who state that diversity might continuously create the turnover conflict. In this case, the Board of Commissioners ethnic diversity may increase the board member conflict and fail to monitor the Management Board effectively and decrease its outcome. Milliken and Martins (1996) supported those who find that directors' ethnic diversity negatively affects individual and company outcome in a company's life. Regarding the finding of the positive relationship between education diversity of Board of Commissioners and international decision, this finding is supported by Díaz-Fernández, González-Rodríguez, and Pawlak (2014) education diversity of directors may enhance problem-solving and decision making in a dynamic environment. In this case, the Board of Commissioners' education diversity makes the Board of Commissioners have better problem solving and therefore, any problem with international politics, economy, society and culture, and technology will be solved better. They have diversity in knowledge, such as the economy and other knowledge. Finally, the Board of Commissioners can assure that international strategy run, and international target could be achieved.

A positive relationship between the Board of Commissioners experiences diversity and international decision. Each Board of Commissioners member brings diverse experiences to the companies. Therefore, it will improve their ability to oversee the Management Board. Kroll et al. (2008) supported that the board experience diversity, Board of Commissioners will monitor and advise and bring about innovative and creative decision making. Therefore, it contributes to strategic planning and conducts the monitoring and evaluation of strategy implementation.

\section{Conclusion and Recommendation}

Global competition has impacted many aspects of the company's life. It has changed the way the company managed. The company has designed the corporate, business unit and functional strategies suited to the business environments to survive. The role of corporate Governance in company internationalization is especially important. A bundle of previous studies on corporate Governance and international decision has been documented. However, the Board of Commissioners diversity as one of the corporate governance attributes has been paid less. Therefore, this study investigates the effect of Board of Commissioners diversity (ethnic, nationality, qualification and experiences). Using service companies listed in Indonesia Stock Exchange (IDX) with 380 company-years, multivariate regression analysis is applied to reject or accept the hypotheses. The result shows that out of four hypotheses being developed, only two hypotheses are accepted: qualification and experience diversity. However, the relationship of the Board of Commissioners ethnic diversity and international decision $(\beta=-0.39 * *)$ is not expected. In addition, company size and leverage have a positive relationship with the international decision.

Practically, this finding implies that the companies that go to the international market or internationalization should reduce the degree of ethnic diversity in companies. Regarding education 
diversity, the company must increase Commissioners education diversity to gain higher international decisions. Further, the company should also increase the Board of Commissioners' experience diversity to achieve a higher international decision. These findings theoretically contribute to the agency theory and resources dependency theory in the Indonesia corporate governance system. These theories can be explained this phenomenon. There are some limitations to this study. First, this study uses the specific companies listed in IDX.

Further, this study focuses on the Board of Commissioners. Finally, this study applies to the multivariate research model. Therefore, there are some avenues for future research. First, future research can consider by widening the research object scopes. Second, future researchers can see international performance from other corporate governance attributes or mechanism, such as the Management Board. Finally, the moderated regression model is also other research opportunities for future researchers.

\section{References}

1. Abdul, W. E. A., Marzuk, M. M., Jaafar, S. B., \& Masron, T. A. (2018). Board diversity and total directors' remuneration: evidence from an emerging market. Pacific Accounting Review, 30(2), 243-272.

2. Alayo, M., Maseda, A., Iturralde, T., \& Arzubiaga, U. (2019). Internationalization and entrepreneurial orientation of family SMEs: The influence of the family character. International Business Review, 28(1), 48-59. https://doi.org/10.1016/j.ibusrev.2018.06.003.

3. Ameer, R., Ramli, F., \& Zakaria, H. (2010). A new perspective on board composition and firm performance in an emerging market. Corporate Governance: The International Journal of Business in Society, 10(5), 647-661. https://doi.org/10.1108/14720701011085607.

4. Arosa, B., Iturralde, T., \& Maseda, A. (2010). Ownership structure and firm performance in nonlisted firms: Evidence from Spain. Journal of Family Business Strategy, 1(2), 88-96. https://doi.org/10.1016/j.jfbs.2010.03.001.

5. Badu, A. E., \& Appiah, K. O. (2017). The effects of board experience and independence on mitigating agency conflict. Journal of Accounting in Emerging Economies, 7(4), 445-467. https://doi.org/10.1108/JAEE-08-2016-0072.

6. Blau, P. M. (1977). A macrosociological theory of social structure. American Journal of Sociology, 83(1), 26-54.

7. Bozec, R. (2005). Boards of Directors, Market Discipline and Firm Performance. Journal of Business Finance \& Accounting, 32(9), 1921-1960. https://doi.org/10.1111/j.0306-686X.2005.00652.x.

8. Calabrò, A., Campopiano, G., Basco, R., \& Pukall, T. (2017). Governance structure and internationalization of family-controlled firms: The mediating role of international entrepreneurial orientation. European Management Journal, 35(2), 238-248. https://doi.org/10.1016/j.emj.2016.04.007

9. Calabrò, A., Torchia, M., Pukall, T., \& Mussolino, D. (2013). The influence of ownership structure and board strategic involvement on international sales: The moderating effect of family involvement. International Business Review, 22(3), 509-523. https://doi.org/10.1016/j.ibusrev.2012.07.002

10.Campbell, K., \& Mínguez-Vera, A. (2008). Gender diversity in the boardroom and firm financial performance. Journal of Business Ethics, 83(3), 435-451. https://doi.org/10.1007/s10551-0079630-y

11.Carter, D., Simkins, B., \& Simpson, W. (2003). Corporate Governance, Board Diversity, and Firm Value. The Financial Review, Wiley Online Library, 38(1), 33-53. https://doi.org/10.1111/15406288.00034

12.Cheng, L. T. W., Chan, R. Y. K., \& Leung, T. Y. (2010). Management demography and corporate performance: Evidence from China. International Business Review, 19(3), 261-275. https://doi.org/10.1016/j.ibusrev.2009.12.007 
13.Cheong, C. W. H., \& Sinnakkannu, J. (2014). Ethnic diversity and firm financial performance: evidence from Malaysia. Journal OfAsia-Pacific Business, 15, 73-100. https://doi.org/10.1080/10599231.2014.872973

14.Chiang, H. T., \& He, L. J. (2010). Board supervision capability and information transparency. Corporate Governance, 18(1), 18-31. https://doi.org/10.1111/j.1467-8683.2009.00779.x

15.Chiang, M.-H., \& Lin, J.-H. (2007). The Relationship between Corporate Governance and Firm Productivity: evidence from Taiwan's manufacturing firms. Corporate Governance: An International Review, 15(5), 768-779. https://doi.org/10.1111/j.1467-8683.2007.00605.x

16.Choi, H. M., Sul, W., \& Min, sang K. (2012). Foreign board membership and firm value in Korea. Management Decision, 50(2), 207-233. https://doi.org/10.1108/00251741211203533

17.Darmadi, S. (2013). Board members' education and firm performance: evidence from a developing economy. International Journal of Commerce and Management, 23(2), 113-135. https://doi.org/10.1108/10569211311324911

18.Darmadi, S. (2016). Ownership concentration, family control, and auditor choice: Evidence from an emerging market. Asian Review of Accounting, 24(1), 19-42.

19.Díaz-Fernández, M. C., González-Rodríguez, M. R., \& Pawlak, M. (2014). Top management demographic characteristics and company performance. Industrial Management and Data Systems, 114(3), 365-386. https://doi.org/10.1108/IMDS-04-2013-0210

20.Erhardt, N. L., Werbel, J. D., \& Shrader, C. B. (2003). Board of Director Diversity and Firm Financial Performance. Corporate Governance, 11(2), 102-111. https://doi.org/10.1111/1467-8683.00011

21.Evers, N., \& Knight, J. (2008). Role of international trade shows in small firm internationalization : a network perspective. International Marketing Review, 25(5), 544-562. https://doi.org/10.1108/02651330810904080

22.Fama, E. F., \& Jensen, M. C. (1983). Separation of Ownership and Control Separation of Ownership and Control. Journal of Law and Economics, 26(2), 301-325. https://doi.org/10.1086/467037

23.Garcia-Torea, N., Fernandez-Feijoo, B., \& de la Cuesta, M. (2016). Board of director's effectiveness and the stakeholder perspective of corporate Governance: Do effective boards promote the interests of shareholders and stakeholders? BRQ Business Research Quarterly, 19(4), 246-260. https://doi.org/10.1016/j.brq.2016.06.001

24.Gujarati, D. (1995). Basic Econometric. Singapore: McGraw-Hill.

25.Hair, J. F., Black, W. C., Babin, B. J., Anderson, R. E., \& Tatham, R. L. (2006). Multivariate data analysis (6th ed.). Upper Saddle River, NJ: Prentice-Hall.

26. Harjoto, M. A., Laksmana, I., \& Yang, Y. (2018). Board nationality and educational background diversity and corporate social performance. The International Journal of Business in Society. https://doi.org/10.1108/CG-04-2018-0138

27. Hossan, C. G., Sarket, A. R., \& Afroze, R. (2012). An Assessment of Managerial Skills in the Labour Intensive Industry: A Case Study of a Garments Manufacturing Firm. Journal of Accounting Business \& Management, 19(2), 1-14.

28.llona, D., Zaitul, \& Ethika. (2019). Supervisory Board and company borrowing: the case of developing economics. Journal of Reviews on Global Economics, 8, 730-738.

29.Jensen, M., \& Meckling, W. (1976). Theory of the firm: managerial behaviour, agency costs, and ownership structure. Journal of Financial Economics, 3(4), 305-360. https://doi.org/10.1017/СВ09780511817410.023

30.Jungmann, C. (2006). The Effectiveness of Corporate Governance in One-Tier and Two-Tier Board Systems - Evidence from the UK and Germany - by. ECFR. 426-474.

31.Kagzi, M., \& Guha, M. (2018). Does board demographic diversity influence firm performance? Evidence from Indian-knowledge intensive firms. Benchmarking, 25(3), 1028-1058. https://doi.org/10.1108/BIJ-07-2017-0203

32.Kampouri, K., Plakoyiannaki, E., \& Leppäaho, T. (2017). Family business internationalization and networks: emerging pathways. Journal of Business and Industrial Marketing, 32(3), 357-370. https://doi.org/10.1108/JBIM-04-2015-0066 
33.Kochan, T., Bezrukova, K., Ely, R., Jackson, S., Joshi, A., Jehn, K., ... Thomas, D. (2003). The effects of diversity on business performance: Report of the diversity research network. Human Resource Management, 42(1), 3-21. https://doi.org/10.1002/hrm.10061

34.Krejcie, R. V., \& Morgan, D. W. (1970). Determining Sample Size for Research Activities. Educational and Psychological Measurement, 30, 607-610.

35.Kroll, M., Walters, B. A., \& Wright, P. (2008). Board vigilance, director experience, and corporate outcome. Strategic Management Journal, 29, 363-382. https://doi.org/10.1002/smj

36.Kuo, H., Wang, L., \& Yeh, L. (2018). The role of education of directors in influencing firm R\&D investment. Asia Pacific Management Review, 23(2), 108-120. https://doi.org/10.1016/j.apmrv.2017.05.002

37.La Porta, R., Lopez-de-Silanes, F., Shleifer, A., \& Vishny, R. (2000). Investor Protection and Corporate Governance. Journal of Financial Economics, 58, 3-27. https://doi.org/http://dx.doi.org/10.1016/S0304-405X(00)00065-9

38.Li, P. Y. (2018). Top management team characteristics and firm internationalization: The moderating role of the size of middle managers. International Business Review, 27(1), 125-138. https://doi.org/10.1016/j.ibusrev.2017.05.011

39.Lian, L., \& Chen, C. (2017). Financial development, ownership and internationalization of firms: evidence from China. China Finance Review International, 7(3), 343-369. https://doi.org/10.1108/CFRI-06-2016-0054

40.Mak, Y. T., \& Kusnadi, Y. (2005). Size really matters: Further evidence on the negative relationship between board size and firm value. Pacific Basin Finance Journal, 13(3), 301-318. https://doi.org/10.1016/j.pacfin.2004.09.002

41.Milliken, F. J., \& Martins, L. L. (1996). Searching for common treads: Undertanding the multiple effects of organizational diversity. Academy of Management, 21(2), 402-433. https://doi.org/10.5465/AMR.1996.9605060217

42.Monks, R. A. G., \& Minow, N. (2004). Corporate Governance (3rd Ed). Boston, MA: Blackwell Publishing.

43.Muttakin, M. B., Khan, A., \& Subramaniam, N. (2015). Firm characteristics, board diversity and corporate social responsibility: Evidence from Bangladesh. Pacific Accounting Review, 27(3), 353372. https://doi.org/10.1108/MBE-09-2016-0047

44.Nam, J., Liu, X., Lioliou, E., \& Jeong, M. (2018). Do board directors affect the export propensity and export performance of Korean firms? A resource dependence perspective. International Business Review, 27(1), 269-280. https://doi.org/10.1016/j.ibusrev.2017.08.001

45.Nas, T. I., \& Kalaycioglu, O. (2016). The effects of the board composition, board size and CEO duality on export performance: Evidence from Turkey. Management Research Review, 39(11), 1374-1409. https://doi.org/http://dx.doi.org/10.1108/MRR-09-2015-0216

46.Nuryanah, S., \& Islam, S. M. N. (2011). Corporate Governance and Performance : Evidence From an Emerging Market. Malaysian Accounting Review, 10(1), 17-42.

47.Oxelheim, L., \& Rand $\varnothing y$, T. (2003). The impact of foreign board membership on firm value. Journal of Banking and Finance, 27(12), 2369-2392. https://doi.org/10.1016/S0378-4266(02)00395-3

48.Ramón-Llorens, M. C., García-Meca, E., \& Duréndez, A. (2017). Influence of CEO characteristics in family firms internationalization. International Business Review, 26(4), 786-799. https://doi.org/10.1016/j.ibusrev.2017.01.007

49.Khan, Nohman, Muhammad Imran Qureshi, Ishamuddin Mustapha, Sobia Irum, and Rai Naveed Arshad. 2020. "A Systematic Literature Review Paper on Online Medical Mobile Applications in Malaysia." International Journal of Online and Biomedical Engineering 16(1):63-82.

50.Rose, C. (2007). Does female board representation influence firm performance ? The Danish evidence . Corporate Governance : An International Does female board representation influence firm performance? The Danish evidence. Corporate Governance, 15(2), 404-413. https://doi.org/10.1111/j.1467-8683.2007.00570.x

51.Segaro, E. (2012). Internationalization of family SMEs : the impact of ownership, Governance, and top management team. J. Manag Gov, 16, 147-169. https://doi.org/10.1007/s10997-010-9145-2 
52.Sakaran, U. (2006). Research Methods for Business: A Skill Building Approach (4th Ed.). New Delhi: John Willey \& Sons Ltd.

53.Shan, Y. G., \& Mclver, R. P. (2011). Corporate governance mechanisms and financial performance in china: Panel data evidence on listed non financial companies. Asia Pacific Business Review, 17(3), 301-324. https://doi.org/10.1080/13602380903522325

54.Siciliano, J. I. (1996). The relationship of board member diversity to organizational performance. Journal of Business Ethics, 15(12), 1313-1320. https://doi.org/10.1007/BF00411816

55.Tseng, C. Y., \& Jian, J. Y. (2016). Board members' educational backgrounds and branding success in Taiwanese firms. Asia Pacific Management Review, 21(2), 111-124. https://doi.org/10.1016/j.apmrv.2016.01.002

56.Ujunwa, A., Okoyeuzu, C., \& Nwakoby, I. (2012). Corporate board diversity and firm performance: evidence from Nigeria. Review of International Comparative Management, 13(4), 605-620. Retrieved from http://search.ebscohost.com/login.aspx?direct=true\&db=bth\&AN=85294714\&site=bsi-live

57.Vencato, C. H. da R., Gomes, C. M., Scherer, F. L., Kneipp, J. M., \& Bichueti, R. S. (2014). Strategic sustainability management and export performance. Management of Environmental Quality: An International Journal, 25(4), 431-445. https://doi.org/10.1108/MEQ-02-2013-0014

58.Wang, Y., \& Clift, B. (2009). Is there a "business case" for board diversity? Pacific Accounting Review, 21(2), 88-103.

59.Yarbrough, E., Abebe, M., \& Dadanlar, H. (2017). Board political experience and firm internationalization strategy. Journal of Strategy and Management, 10(4), 401-416. https://doi.org/10.1108/JSMA-07-2016-0043

60.Zaitul, Elfiswandib, \& Ilonab, D. (2019). Board of commissioners involvement and shareholder's wealth. International Journal of Recent Technology and Engineering, 8(2 Special Issue 9), 484-490. https://doi.org/10.35940/ijrte.B1107.0982S919

61.Zaitul, \& Ilona, D. (2018). Gender in Audit Committee and Financial Reporting Timeliness : the Case of Unique Continental European Model. International Journal of Engineering \& Technology, 7(2.29), 436-442. https://doi.org/10.14419/ijet.v7i2.29.13668

62.Zaitul, Melmusi, Z., \& Ilona, D. (2019). Corporate Governance and corporate performance: Financial crisis 2008. Journal of Reviews on Global Economics, 8, 625-636.

63.Zaitul, Ridwan, M., \& Pratiwi, H. (2018). Dividend policy in Indonesian companies: Does corporate governance matter? International Journal of Engineering and Technology(UAE), 7(3.25), 306-310. https://doi.org/10.14419/ijet.v7i3.25.17587 